\title{
RASSEGNA
}

\section{GIANNA MANZINI'S RITRATTO IN PIEDI: PORTRAIT AND CONFESSION}

Ritratto in Piedi, Gianna Manzini's last novel published in 1971 just a few years before her death in 1974, is both a lyrical portrait of her father, and a portrait that is also a confession. While Giovanni Manzini is the central figure, the emotional intensity of the book does not come from him, but from his daughter's posture toward him, charged as it is with her feelings of guilt and remorse. The portrait of the father is filtered through the consciousness of the daughter. In dealing with him, she has had to deal with herself. Given the special relationship of the author-narrator to her subject, the book cannot be an objective, detached biography. Because of this special involvement the material introduced is as the same time autobiographical. As all the digressions into the past are effected by the narrator who refuses a rationalized approach to reality, we are confronted with her monologue in a constant imagistic flow. Past experiences are relived in their perceptual and emotional concreteness. Through the dimension of memory, they are broken out of their solidity into sensations, perceptions, feelings, thoughts that images catch and keep alive. Events do not follow a causal chain of development. They evolve rather from an associational process as they come into the periphery of the narrator's consciousness. Choosing pattern over plot, the associative flux of memory over logic, the author leads the novel away from a conventional form to the non-linear one of poetry.

A structurally vital element which makes for unity and perspective is the temporal standpoint provided in Ritratto in Piedi by the narrator's visit to her father's grave. This is the only scene in the book which takes place in the present. From it stems the narrator's confession and her search into the past. Hence this scene, besides functioning as the structural framework for the story, becomes its emotional filter. While the flux of memories brings about a series of scenes that are really separable from each other, they all gravitate around this grave, this penitence, this confession. 
Paradoxically, it is from the fixity of this center that the book acquires its freedom, its spatial and temporal fluidity.

The confessional tone that the narrator has assumed in front of ther father's grave is heightened by her need to track down something within her that evades her. With this private devil she is willing to accept a duel, a duel that reminds us of one of those medieval " débats" in which the soul became engaged. Certainly this tendency to carry on a relentless self-analysis makes this character a spiritual heir to Petrarca. Ritratto in Piedi can indeed be read as Gianna Manzini's Secretum, for in it too we meet a sensitive soul in the grip of self-doubt and frustration. We find in both the same impulse to confess a sense of guilt and the same skepticism of ever being able to resolve the dramatized conflict. In both cases the author has chosen his or her art as the medium through which the inner crisis is not only cronicled but explored. Only Ritratto in Piedi does so lyrically, for the Secretum lacks the Canzoniere's lyrical utterances. When present in Ritratto in Piedi, abstract analysis assumes a tautological role. At no time is the exchange between the character and the world around her allowed to fade into abstractions. We are not seized by the force of an argument but by an emotional, lyrical intensity.

The memory scenes that evolve from the standpoint or from one another are all related to the emotional nucleus of the book, the need to confess which is really carried out through the evocation of the father daughter relationship. No scene from the narrator's childhood or adolescence is irrelevant to it, none fails to illuminate it in part. Its exclusiveness is kept throughout. Because of it, the book is not finally centered on the social and political analysis of the author's own generation and milieu. Not that social and political issues are foreign to it, for its central figure, the father, can be seen as a victim of social and political forces. Opposed to Fascism and to middle-class conformity, he sacrifices to his political ideology his domestic happiness, his freedom and ultimately his life. The overall lyrical tone of the novel, however, while excluding a preconceived intellectual treatment of the social and political issues, lets them nonetheless permeate the story.

The visit of Gianna Manzini to her father's grave is symbolic of the exclusiveness in which the father-daughter relationship is kept. She comes alone to the lonely grandeur of this secluded spot of Cutigliano up in the Apennine Mountains. She brings to it her burden of guilt and her memories, everything else is left behind. 
It is significant that most of the flashbacks take the form of a visit, so that the "visit," besides symbolizing the central emotional issue of the book, becomes a basic thematic and structural element. We see the narrator as a child visiting her father's jewelry store, we see her going with him to visit his friends at a secret political meeting in the country. Later we meet her as an adolescent as she goes to visit her outcast father at Cutigliano. Of all such visits, the one to the grave is the last in the series, and it comes full circle in allowing mental time to catch up with the present. In Ritratto in Piedi, the author herself calls memories " rapidissime visite," ${ }^{1}$ a beautiful metaphor for her "modus operandi."

At the end of the book, we still find her here. Only a short time has passed yet we get the ambiguous feeling of both having stood still in time and of having traveled a great deal through it. This has been brought about by the rhythmic duality between the fixity of the present task and the lyrical inventory of the past. The rigidity of the expiatory frame that holds the book in its grip is constantly relaxed, the painful posture of the "flagellante" is constantly making room for the free play of the "immaginifica." In moving from inquest to quest, the taxing Secretum turns itself into Recherche. Yet it is precisely because the elegy is conditioned by a moral imperative that does not allow it to become effusive, self-indulgent, that the book gains its moral value. The author herself summarizes all this for us with her stated intent to: "Udire, vedere: una collisione, sia pure irresistibile, in un sovrapporsi di tempi: lastre trasparenti di tempi, anni, lustri, decenni, connesse in un presente assoluto." 2

Here "udire," "vedere," hammered with imperative force, point to her urge for sudden visions, for flashes of insight. The image "lastre trasparenti di tempi," besides giving a spatial quality to the abstract concept of time, condenses the mystical urge to see through it.

Like the sacrament of confession, Ritratto in Piedi, made up of eight chapters, is preceded by a long introductory one appropriately entitled "Atto di Contrizione." It functions as the novel's overture, containing "in nuce" all its basic elements.

Having established the moral purpose and the emotional tone of the book, the narrator moves on to clearly define the lines of her conflict by conducting a symbolic kind of trial against her family and her city. But the impulse toward this kind of revisionism is as always offset by the countertendency that keeps on turning scrutiny 
into lyrical evocation. It is at one such moment that her native city of Pistoia appears:

Che città, a quei tempi, Pistoia: viatici, funerali, campane a morto, campane a festa, fanfare, bisbigli, bisbigli, bisbigli; e monti bellissimi, turchini, a cingerla da est a ovest, alitando, quella pungevolezza d'aria odorosa, un frizzo incitante; [...] E i nomi di alcune strade. Via del "T," via del Pizzicore, via Abbipazienza...; e il giardino pubblico di piazza Mazzini, col busto di Cino: una pena vedergli il naso rotto, a lui, un poeta; e l'ora rituale del passeggio, al tramonto, con le ragazze da marito, due passi avanti alle mamme e alle zie; e i tanti odori. Ma esisteranno ancora? Ogni terrazza versava torrenti di glicine; e che gara, fra chi aveva orti e giardini, per la piantina che nessuno ce l'ha, rèseda, vaniglia... ${ }^{3}$

It is in this immediate, lyrical "compositio loci" that we are introduced to Pistoia, Pistoia as a physical, particular reality. The whole scene is set in imagistic terms. We may notice in passing the light, gentle touch of humor about Cino da Pistoia, a touch so elegant and perfectly Tuscan in its lineage. We may also notice the way the author works with visual quantities, moving freely from distanced perspectives to close ones. In brief, impressionistic strokes, she recreates for us the look and feeling of a place and an hour.

In the presentation of Pistoia the basic principles of construction are those of parallelism and contrast, the same on which the whole novel depends to cohere and to establish its meaning. By applying them to characters and events, the author makes all kinds of thematic statements, establishes all kinds of ironic nuances. This layering of experience is appropriate in a novel that depends on inner resonances for its unity, and that tends to put characters and events on a symbolic plane. An example of such significant contrast can be seen in the juxtaposition of the ritual of the evening stroll to the anarchists' march that comes to upset it:

$\mathrm{E}$ in questo tran-tran, in questa noia organizzata, lo scossone degli anarchici. Passavano, cantando. [...] Passavano. Quanti? Pochi. Trenta, quaranta. Ma l'ordimento li moltiplicava; e moltiplicava lo sventolio delle bandiere. La decisione del passo poi sbalordiva. ${ }^{4}$

The totally abstract image of " noia organizzata" catches perfectly the insular mood of a provincial afternoon. The "scossone degli anarchici" that shatters it is a most striking contrast to it. 
Any statement that the little scene makes about the anarchists is mostly deduced from their physical, visual impact. Through images that express their intensity and enthusiasm, we see them as possessors of a truth that leads them to improvise a different rhythm and trace a different path from those around them.

Here, as everywhere else in the novel, the scene and the counterscene emerge quickly and spontaneously from one another without any transitional summary. An adverb of time or an adverbial phrase at the beginning of the scene may furnish the only link. Instead of producing paratactical monotony, the effect of such a process is here one of fugal swiftness that keeps up the momentum of the whole, and that creates the impression of continuity despite the constant sliding and shifting of the spatial and temporal planes. At other times, a space jump in the page is the only indication of transition between scenes. Gianna Manzini makes this common modern practice work in her fiction. Unburdened by long transitional passages, the scenes become the novel's basic units. Taking the license of a poet, the author arranges them into a formal whole that is coherent and meaningful.

By the end of the introductory chapter, the emergent pattern of the book is clear to us. The juxtaposed scenes that illuminate one another do not appear independent of the narrator-"dramatis persona," and it is with them that she is going to fill in her portrait. Any tension in the book will have to arise from within her. By sustaining a now-then dialectic, the present poised rigidly on the confession, the past bringing in the flux of memories, by making the two levels meet almost always at a high point of intensity, the author keeps her book consistently readable. The next scene is always caught in the urgency that drives the book on.

Ritratto in Piedi is a biography that begins at its subject's death instead of his birth. A biography that does not give us a string of successive events in the life of a man, but that is nonetheless a life story. Gianna Manzini's method of portraiture does not fail her. The bits and pieces of memories with which she builds the portrait of her father give it a life that continues to grow in amplitude.

Characterization in Ritratto in Piedi is submitted to the same associational process of the whole. Throughout the book, the father is felt as a presence. Nowhere is such a presence felt more keenly than at the grave scene at Cutigliano. In this remote little town Giovanni Manzini had spent the last years of his life under house 
arrest by Fascist order. Now the daughter, kneeling in front of the neglected grave, in the act of weeding some wild growth that is slowly overtaking it, hears a voice within her urging her to admire and respect those wild weeds, those "erbacce ":

Di molte piante, lui avrebbe saputo il nome; e non gli sarebbe piaciuto che si dicesse "erbacce." "Erbacce, perché non servono a te? Perché non ti piacciono? Perché t'intralciano?" sicuro, che me lo sussurrava all'orecchio. [...] "Erbacce perché l'uso vuole che si distruggano? Nascono condannate le erbacce." [...] "Perché ti umilia quest'eccesso gratuito di impulso vitale? [...] E vita, Giannina, è vita!" 5

Here a physical element from the scene itself has become part of the internalized speech of the narrator. This process wherein an element from physical reality becomes an element of the character's consciousness and expression is a poetic process basic to this lyrical novel of Gianna Manzini. Projected as an image, it carries the meaning of the scene. As a symbol the "erbacce" represent one of the father's most noble traits, his Franciscan love for all creatures and things, his all-embracing acceptance of life. In the same scene, this image is followed and reinforced by another:

Avrebbe voluto per la sua sepoltura, e lo disse, non fiori; bensì piccole ciotole col miglio per gli uccelli. Quanti ne sarebbero venuti. Che canti, che voli dall'alba al tramonto. Che compagnia. «E non per me soltanto." 6

How well does the remembered wish turned image express the spirit of the man so close to that of the "poverello " of Assisi!

Besides these, certain objects dear to him are repeatedly used as symbols of the man, of his loyalty to human relationships, of his love of justice. We find an instance of this in the story of the little penknife, the "temperino" that, like the "topo bianco" 7 of Dora Markus in Montale's Le Occasioni, became Giovanni Manzini's good-luck charm. In a remembered "visit "-scene, we hear the father tell the story through which, as in a medieval "exemplum" the child is instructed on justice and beauty. We learn of how he received the little penknife one day as a gift from a young seminarian friend whom he had defended against an injustice suffered from a superior; of how later in life he had lost it and found it again in 
a field of lilies while crossing the Pyrenees on his way to a political mission in Spain; of how from then on it had become his amulet. In tracing this little story we are made to trace the pattern of his existence, we are made to feel the force of his ideals. The aim of the book is all here, which is not to tell the day to day story of his life, as it is to capture its beauty, its nobility, its strength.

No less than the "exemplum," the fable is a much used narrative device in Ritratto in Piedi. The fable in this novel, as well as in Gianna Manzini's narrative in general, is not meant to lead us to any moral but to draw us immediately into the world of the character. Built into a metaphor that generates both an emotional and an intellectual response, it is usually fragmented throughout the scene in which it appears. This fragmentation is neither purposeless nor casual, but basic in establishing the pace of the scene, its rhythm, its visual direction. Both structurally and thematically, the fable counterpoints the character's mental processes during a particular situation or event in which he finds himself. One such associational insert occurs in Ritratto in Piedi when the narrator evokes an afternoon spent long ago with her father at an anarchists' meeting in the country. The meeting in itself is not presented in detail, at any rate it is not presented from their point of view. We observe them gathered around a table, we overhear their singing, but the afternoon is presented totally as the child's reality. Her special way of being in it makes all the difference. It is her subjective experience of the event that we live through. Nothing is seen independently of her. The child and the world around her are here related at every point, separation is totally transcended by lyrical immediacy. As the child's eye leads us through the scene, we see the frame of view widen from the anarchists' table to even include the sky at times or to narrow down to a less distanced perspective as it does when it cuts to an upper window of the farmhouse framing a dog:

A una finestra di lato, molto più piccola delle altre, sicuramente la finestra d'un ripostiglio, c'è un grosso cane di guardia. Affacciato come un uomo, appoggia le zampe sul davanzale. Guarda a orecchi ritti, zitto. Scende, sparisce per un momento, ricompare, sempre nella stessa posizione.

Il ragazzo del grappolo d'uva mi confida: "Sai, di qua e di là, dove tiene le zampe, ci sono come due scannellature, due fosse. A star sempre 1i, legato, struscicando, premendo, in due anni ha consumato il davanzale." 8 
When at intervals her eye comes to rest on the dog, it forces us to focus on a series of closeups and " rallenti," the effect of which is to arrest time, magnify feelings, and increase the emotional charge of the whole. Here again an element clearly observed in actual reality is turned into a symbol that defines and condenses the child's feelings and thoughts toward her father and his friends. There is no lengthy abstract explanation of their ideals, their goals, their sympathy for the oppressed. Instead meaning is here once more arrived at through the pictorial concentration and the associational implications made by the little apologue.

As it is the vision of the character that unifies the scene for us, it is her love of detail that makes it come alive. Its mood is created by the constant accretion of images whose effect is both immediate and cumulative.

One is by now aware of the large role that description plays in this book. This is true of Ritratto in Piedi as a whole and of Gianna Manzini's lyrical novels in general. In fact description can prove to be an identifying element if close attention is paid to its specific nature, to the distinct kind of dynamics that operate in it.

Description in Gianna Manzini's novels is never static. The character does not survey the world around her in a neutral state. Whether moving the outside phenomenon to his or her consciousness or the other way around, there is always a fusion of the two taking place at the threshold of the character's consciousness. It is at this specific moment that description becomes lyrical song.

In illustrating this process we may consider briefly how a diametrically opposed attitude toward this relationship conditions the French Nouveau Roman. Alain Robbe-Grillet, the well known and articulate theoretician and practitioner of the Nouveau Roman, proposes to do away with any subjective dimension when confronting physical reality in fiction, opting instead for a purely objective presentation. In his collection of essays, Pour Un Nouveau Roman, he states that "autour de nous, défiant la meute de nos adjectifs animistes ou ménagers, les choses sont là. Leur surface est nette et lisse, inctacte, sans éclat louche ni transparence." ${ }^{9}$ Continuing in the same vein, he later states that "nous constatons, de jour en jour, la répugnance croissante des plus conscients devant le mot à caractère viscéral, analogique ou incantatoire. Cependant que l'adjectif optique, descriptif, celui qui se contente de mesurer, de situer, de limiter, de définir, montre probablement le chemin difficile d'un nouvel art romanesque." ${ }^{10}$ But such objectives can only be reached at the cost 
of ignoring what poets have always known, namely that sight is not a disinterested process, that to see is to feel. Even the simplest experience of physical reality requires a feeling for its nature that is never just a mechanical reaction. Perception is always both an external and an internal process, conditioned as it is not only by external stimuli but by memory and imagination as well. The reliance on it as a purely mechanical process is at the root of Robbe-Grillet's position. Maurice Merleau-Ponty in Phenomenology of Perception provides us with the exact explanation we have been looking for when he says,

I am not the outcome or the meeting-point of numerous casual agencies which determine my bodily or psychological make-up. I cannot conceive myself as nothing but a bit of the world, even my scientific knowledge, is gained from my own particular point of view, or from some experience of the world without which the symbols of science would be meaningless [...] Scientific points of view, according to which my existence is a moment of the world's, are always both naive and at the same time dishonest, because they take for granted, without explicitly mentioning it, the other point of view, namely that of consciousness, through which from the outset a world forms itself round me and begins to exist for me.11

For the character in Gianna Manzini's lyrical novel such a divorce of points of view could not be possible, nor could he or she do away with metaphoric expression. Like a Symbolist poet, this character seeks the hidden connections between things. Going all the way, he may reach the extreme position of the mystic who sees them, but it is always with this kind of vision that he invests the world he describes.

In Ritratto in piedi, the intensity of the child's gaze is not confined to the physical and the animal world. Her mother especially receives it. In a book where the mother has been a fleeting, marginal figure, she remains in the end an impression caught by many images of charm and elegance. There is a Dannunzian touch to the portrait of this "Belle Epoque " exquisite creature. But she receives a rather severe treatment in the last scene in which she appears. In the end suffering fails to absolve her in the eyes of her daughter who points an indicting finger at her mother's self-denial and renunciation. Her husband's shop having been robbed, he is about to leave Pistoia in an effort to start all over somewhere else. Those responsible for 
the crime are never found. Fascist involvement is suspected by some who see the robbery as a pretext to force the anarchist, Giovanni Manzini, out of town. Unwavering in his inner consistency, he refuses to denounce the crime. Before leaving he offers his wife a silent invitation to join him. This forces her into a choice between her husband and her family with whom she has been living. Her courage ultimately fails her, she hesitates but a moment, remaining trapped by her family, her social class, "splendido, stupido uccello impagliato su una gruccia." ${ }^{12}$ The tremendous, grotesque image with which the narrator dismisses her mother is a truly condemning one. We should not miss the force of each word, the emctional chain reaction each sets off. The alliterative intensity of " splendido" and "stupido" clenches the truths and contradictions implied about the character throughout the book. "Impagliato" suggests a life-less state. The character has in fact refused to be drawn back into life. "Su una gruccia " reinforces all this by suggesting a certain maiming of the self. Of special interest are the connotations of "gruccia," a word used in Italian for crutch, for clothes hanger, as well as for perch.

How different in this book of constant interplay of contrasts is the way in which the narrator takes leave of her father! From chapter six on, the confessional monologue becomes the intense and dominant note of the book. Interwoven as it has been throughout the novel, it has served to juxtapose the pure moments of memory with the agony of the present conflict. It has been the unifying thread that has held the disconnected scenes together, making us realize that we have not been simply reading a book of childhood recalled, but of childhood recalled under a present need, under a moral imperative.

In chapter six the narrator's soul-searching comes to a head. She comes face to face with its object, the word " remorse " appears:

Sia pure in maniera ottusa, l'avevo sentito che, raccontando la storia di lui, sarei arrivata a questo punto: in una zona d'ombra lavorata da un tarlo che, risalendo dal profondo, a lungo, a lungo mi aveva incalzato, sgretolando. Figuriamoci se non ce la facevo a tirarmi indietro, a tergiversare; con garbo, si capisce, con garbo propiziatorio. $\mathrm{Si}$ che mi rifugiavo nei ricordi di me bambina, con lui accanto, e della nostra straordinaria alleanza. Che luce bella, che vasta chiarezza, in quel tempo, anche se si trattava di dolore. Ma quel tarlo non mollava. Finii col percepire il suono del suo rosicchìo. Finché un nome dovetti pur darglielo a questo segugio paziente: il suo vero nome. Rimorso, si chiama. ${ }^{13}$ 
Once we have reached this stage of development in Ritratto in Piedi, we feel that the moral purpose of the book has been fulfilled. Memory, the expiatory and the revelatory means, has sustained the character's search, and has brought her to face the self-truth that has evaded her up to now. Having come to grips with it, she then moves to a series of self-accusing memories that show the physical forces that went into the making of her guilt feelings, the moral offenses of indifference and neglect that she now knows she committed against her father. At the end with " ora ascoltami babbo," ${ }^{14}$ the confession which began with an act of contrition, turns itself into prayer. The narrator is still kneeling at her father's grave which has been her confessional. At this point portrait and confession are one. We see the book all at once in its totality. We realize that it could not have been told in any other way nor from any other point of view. This has been her story, and this is how she has chosen to tell it, a tissue of memories each a deft stroke in setting the portrait of her father standing in front of us. The fragmentation of the story has not antagonized the nature of our being, for this is actually how the past comes back to us, in bits and pieces and in images just as dreams do. This is how from a fixed point in space and time, memory has given her the freedom to telescope time in a forever-Now that has managed to close the gap between past and present, father and daugther, life and art.

\section{University of Oklaboma}

\section{ROSETTA d. PICLARDI}

1 Gianna Manzini, Ritratto in Piedi (Milano: Mondadori, 1971), p. 66.

2 Ibid., p. 15.

3 Ibid., p. 16.

${ }^{4}$ Ibid., pp. 17-18.

${ }^{5}$ Ibid., pp. $58-59$.

${ }^{6}$ Ibid., pp. 60-61.

${ }^{7}$ Eugenio Montale, “Dora Markus," in Le occasioni (Milano: Mondadori, $1967)$, p. 41.

8 Manzini, op. cit., p. 142.

${ }^{9}$ Alain Robbe-Grillet, Pour un Nouveau Roman (Paris: Gallimard, 1963), p. 21 .

10 Ibid., p. 27.

11 Maurice Merleau-Ponty, Phenomenology of Perception, trans., Colin Smith (New York: Humanities Press, 1962), pp. viii-ix.

12 Manzini, op. cit., p. 182.

13 Ibid., p. 189.

14 Ibid., p. 223. 